\title{
Management of dental office during COVID-19 Pandemic
}

\author{
Sri Sowmya K${ }^{1, *}$, Ravi Kumar C², Sujesh $\mathbf{M}^{2}$, Pavani Lukka ${ }^{3}$ \\ ${ }^{1}$ Postgraduate Student, 2 Professor, ${ }^{3}$ Senior Lecturer Mamata Dental College, Giri Prasaad Nagar, \\ Khammam, Telangana, India -507002.
}

\section{N F O R M A T I O N A B S T R A C T}

\section{Article History \\ Received $15^{\text {th }}$ September 2020 \\ Received revised \\ 29th December 2020 \\ Accepted $12^{\text {th }}$ January 2021 \\ Available online \\ 22 $2^{\text {nd }}$ February 2021}

\section{K E Y W O R D S}

COVID-19

Infection control

Patient management in dental clinics
Novel Coronavirus (COVID-19) is a deadly protein molecule devastating the humankind and has brought down the life to a standstill. Its effect is determined by the interaction among the agent, the host and the environment. The proven fact that the spread of COVID-19 is air-borne has made it mandatory for the dental fraternity to follow a systematic protocol in clinical practice. A proper history of travel and exposure, thermal scanning, symptoms of sore throat, dry cough and difficulty in breathing makes you suspect an individual with COVID-19. It is imperative to consider only emergency and essential dental procedures to be carried out under strict aseptic measures, not only for suspects but also for routine patients.

COVID-19 and dentistry are very closely related to each other as the dental professionals are directly working in the oral cavity. Although the Ministry of Health \& Family Welfare has issued comprehensive guidance to prevent the occurrence of hospital-acquired infection (HAI) in health facilities, the practice of universal precautions might still be lacking in many dental professionals due to improper knowledge. Data acquisition was carried out using the keywords, COVID-19, control of infection, and patient management in dental offices in PubMed, Medline, ProQuest, etc., electronic databases. There was also a manual scan of many journals and books, and highly relevant papers were considered for the present study.

\section{Introduction}

Because of the SARS-CoV-2 outbreak, the dental fraternity is undergoing a dramatic transition and will continue to do so over the coming weeks and months. The implications, particularly for the dental community and patients seeking dental care, are far-reaching and unpredictable. A National Institute of Health $(\mathrm{NIH})$ study found that SARS-CoV-2-containing aerosols remain infectious for up to 3 hours in enclosed spaces, four hours on copper, 24 hours on cardboard, and three days on stainless steel and plastic. During dental care, the use of an ultrasonic scaler, a triple syringe, dental handpiece, and other high-speed powered tools will produce substantial quantities of aerosols, placing dental practitioners, dental teams, and their patients at high risk of COVID-19 [1].

\section{Structure of novel Coronavirus}

The 2019 novel coronavirus (2019-ncov) has spread rapidly to the rest of the world from its roots in Wuhan City, Hubei Province of China. [2]. On 11 February 2020, the World Health Organization (WHO) declared the epidemic disease 
effected by 2019-ncov as coronavirus disease (COVID19).

Coronavirus is a huge group of viruses that cause ailments ranging from the common cold to more infectious complications such as Middle East Respiratory Syndrome (MERS-Cov) and severe acute respiratory syndrome (SARS-Cov). Coronaviruses spread from animals to humans (zoonotic) [3,4]. Coronaviruses are huge, ranging from $60 \mathrm{~nm}$ to 140 $\mathrm{nm}$ in diameter [5], encased, positive-stranded RNA viruses. They have a gigantic genome among all RNA viruses. The genome is filled inside a helical capsid formed by the nucleocapsid protein and encircled by an envelope. Analogous with the viral envelope are three structural proteins: the membrane protein and the envelope protein are entangled in virus assembly, whereas the spike protein (S-protein) regulates virus entry into host cells and forms huge protrusions from the virus surface among the structural proteins, giving coronaviruses the illusion of having crowns (hence their name; corona, in Latin, means crown). The spike is an important stimulus of viral host range and tissue tropism as well as a significant inducer of host immune responses, apart from controlling the virus entry (Figure1).

Coronavirus causes respiratory, gastrointestinal and central nervous system diseases in humans and other animals, alarming human health from mild upper to lower respiratory tract infections [3].

The SARS-cov-2 is a recent strain of coronavirus that was first noticed in Wuhan's city, in the Hubei province. SARS-cov-2 primary origin is still unmapped, although the earlier cases were linked to the Wuhan city's Huanan seafood market [6].

Of late, several studies have advocated that bats may be the possible natural host of SARS-Cov-2 [7]. The whole genome-wide nucleotide sequence of SARS Cov2 is $96 \%$ identical to a bat CoV. Notably, SARS-CoV-2 has been sequestered from pangolins, and it was found to have $-85.5-92.4 \%$ similarity to SARS-cov-2, suggesting that pangolin may be a potential intermediate host for SARS-cov-2.

\section{Transmission route of SARS-cov-2}

The SARS cov-2 communicate between humans via respiratory droplets, Close Contact, direct or indirect contact with mucous membranes in the eyes, mouth or nose [8], aerosol transmission in a relatively closed environment with constant vulnerability to high concentrations of aerosol. Moreover, it has been outlined that COVID-19 patients have some gastrointestinal symptoms, including diarrhoea, nausea and vomiting (Figure 2) [9].

Dental professionals are more vulnerable to COVID-19 infection due to close face-to-face contact [10]. Therefore, a dental professional must cease the regular treatments and treat only the emergency cases to limit the spread of COVID-19 among their patients and beyond.

This virus's spread is commonly seen in household contacts, health care professionals not wearing personalised protective equipment (PPE) and in closed settings like social or work gatherings. Extensive SARS -cov-2 pestilence of environmental surfaces in hospital wards of patients with COVID-19 has been described [2].

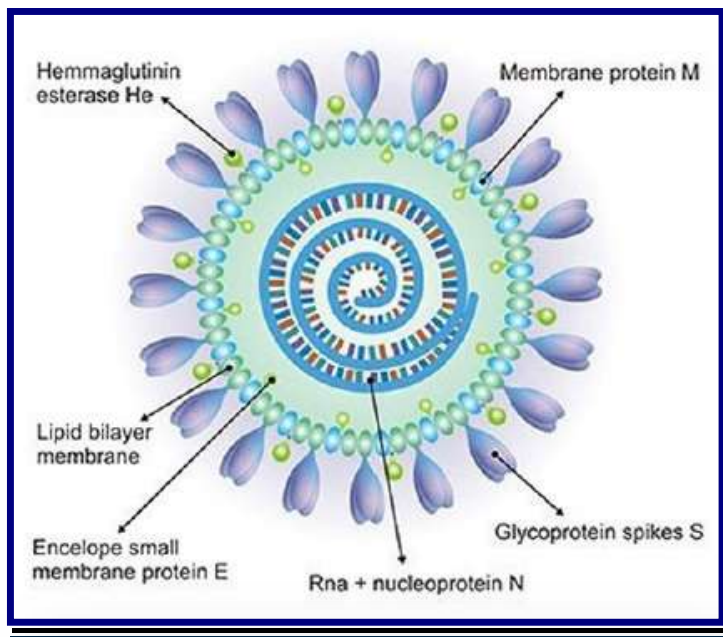

Figure 1. Structure of SARS - CoV virus.

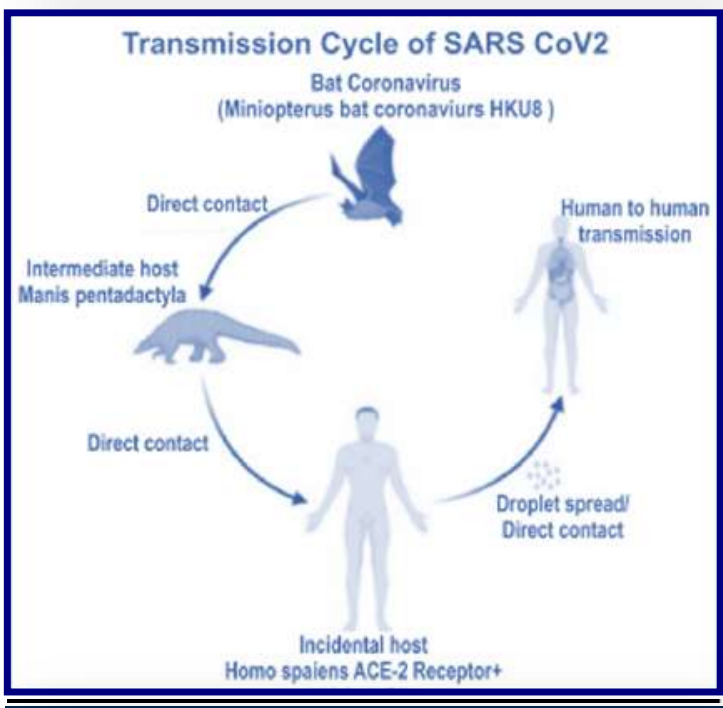

Figure 2. Transmission cycle of SARS-CoV 2 . 


\subsection{Period of infectivity}

According to a modelling study in China [11], the covid -19 has a mean survival interval of 5-8 days between the onset of symptoms. The infection starts 2-3 days prior to symptom onset, peaked 07 days before symptom onset, and declined within seven days [12]. Transmission of virus has also been reported from asymptomatic individuals within the incubation period [12].

\subsection{Clinical features}

Clinical features and symptoms of Covid-19 are described in tables 1 and 2 respectively [13].

\section{Preventive measures}

- Social Distancing - maintaining a distance of one meter (3 feet) between two individuals at all times.

- Regularly and thoroughly cleaning hands with alcohol-based hand rub and washing with soap and water. Avoid touching face, nose or eyes.

- Respiratory hygiene: Covering mouth and nose with a cloth/tissue or bend an elbow while coughing and sneezing. Dispose of the used tissue immediately into a covered dustbin operated by foot. Home quarantine and self-isolation.

- Keep up-to-date information using official government portals [14].

\section{General implications of Covid- 19 on global dental practice}

Many countries have shut down routine dental care in a similar way to China. But many dental clinicians reduced routine dental care for fear of spreading COVID-19 among their patients and others [15]. Therefore, dentists need to optimise preventive strategies by focusing on patient positioning, hand hygiene, and all PPE to avoid COVID-19 infection. The pre-check triages established in clinics and hospitals to record the temperature of every staff and patient. Preoperative antimicrobial mouth-rinse provided for every patient to reduce the bacterial load. Use of rubber-dam and high-volume suctions during a dental emergency procedure. Separate entry gates for patient and dentist along with the use of PPE (Figure-3) [16].

\subsection{Treatment categorization}

To develop these guidelines, it is proposed to divide dental procedures into five categories (Table 3, Figure. 4).

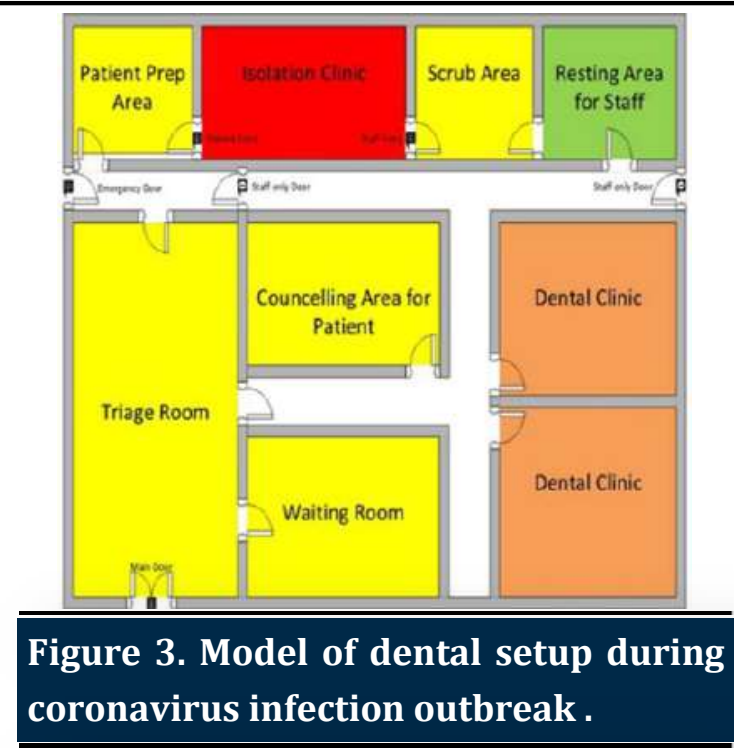

A. Emergency management of life-threatening conditions.

B. Urgent conditions that can be managed with minimally invasive procedures and without aerosol generation.

C. Urgent conditions that need to be managed with invasive and/or aerosol-generating procedures.

D. Non-urgent procedures.

E. Elective procedures.

\section{Guidelines for Reopening Dental Offices Safely During the COVID-19 Pandemic}

These practices are designed to protect dentists, dental health care personnel (DHCP) and prevent DHCP from spreading infections among patients. Standard precautions include [18];

- Hand hygiene.

- Personal protective equipment (for example, gloves, masks, eyewear).

- Respiratory hygiene/cough etiquette.

- Sharps safety (engineering and work practice controls).

- Secure injection procedures (i.e., aseptic parenteral drug technique).

- Sterile instruments and devices.

- Clean and disinfected environmental surfaces.

\subsection{Personal Protective Equipment}

Considering those asymptomatic patients, COVID-19 can still be contagious, and it should be assumed that all patients may transmit the disease. To mitigate the chances of exposure, use the maximum available amount of PPE while treating patients. Dentists should exercise their own clinical judgment and cautiously 
Table 1. Clinical features of COVID-19 [14]

\begin{tabular}{ll}
\hline Spectrum & Clinical presentation \\
\hline Mild & No pneumonia. \\
Moderate - severe & Dyspnea, hypoxia, $>50 \%$ involvement of lung on imaging within 24- 48 hours. \\
Critical & Respiratory failure, shock, multiorgan dysfunction.
\end{tabular}

\begin{tabular}{lll}
\hline Table 2. Symptoms COVID-19 [14] & & \\
\hline Common symptoms & Less common symptoms & Rare symptoms \\
\hline Fever & Myalgia/arthralgia & Nausea, vomiting \\
Cough & Head ache & Nasal congestion \\
Fatigue & Sore throat & Diarrhoea \\
Shortness of breath & Chills & Palpitations and chest tightness \\
\hline
\end{tabular}
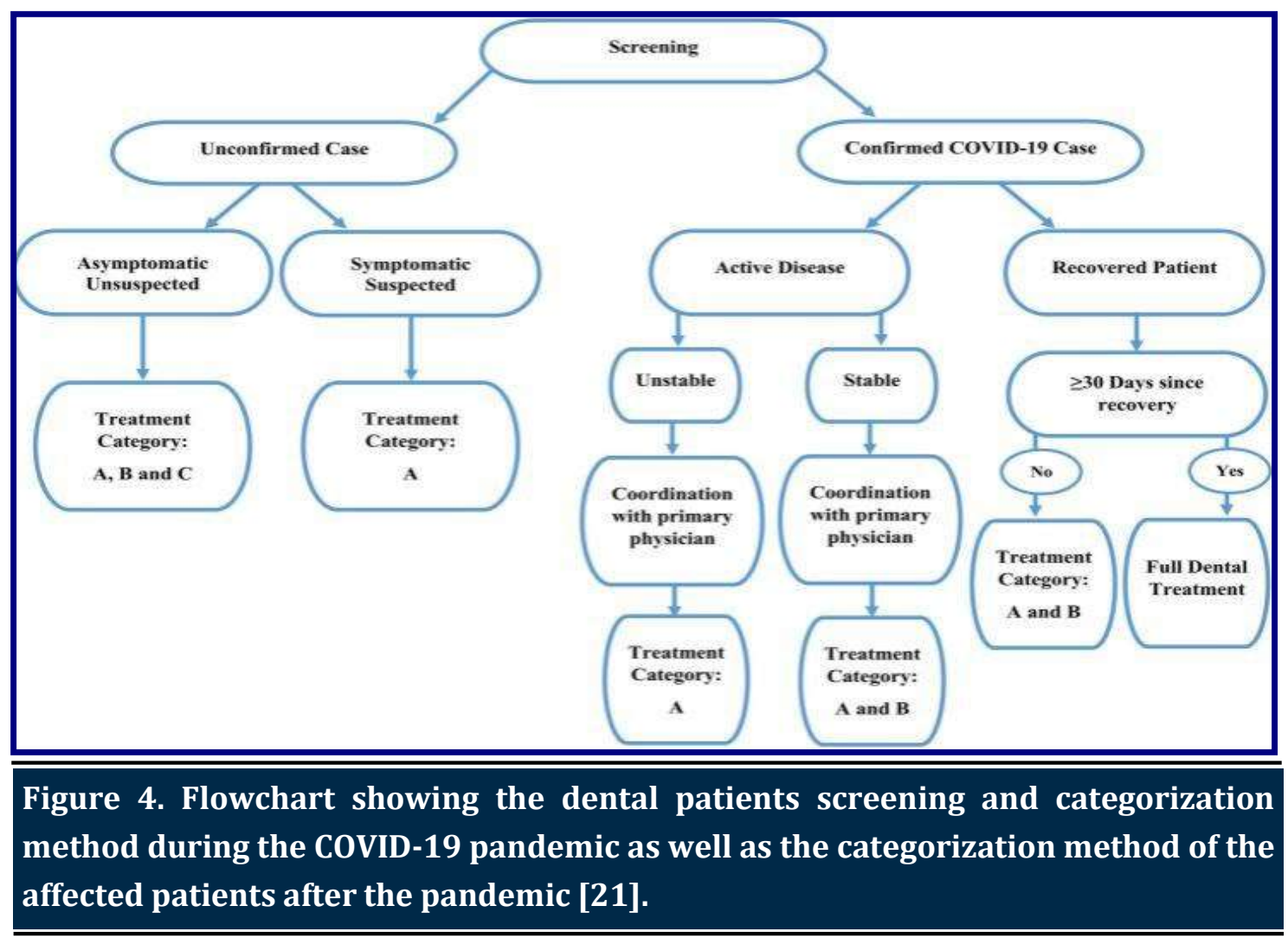

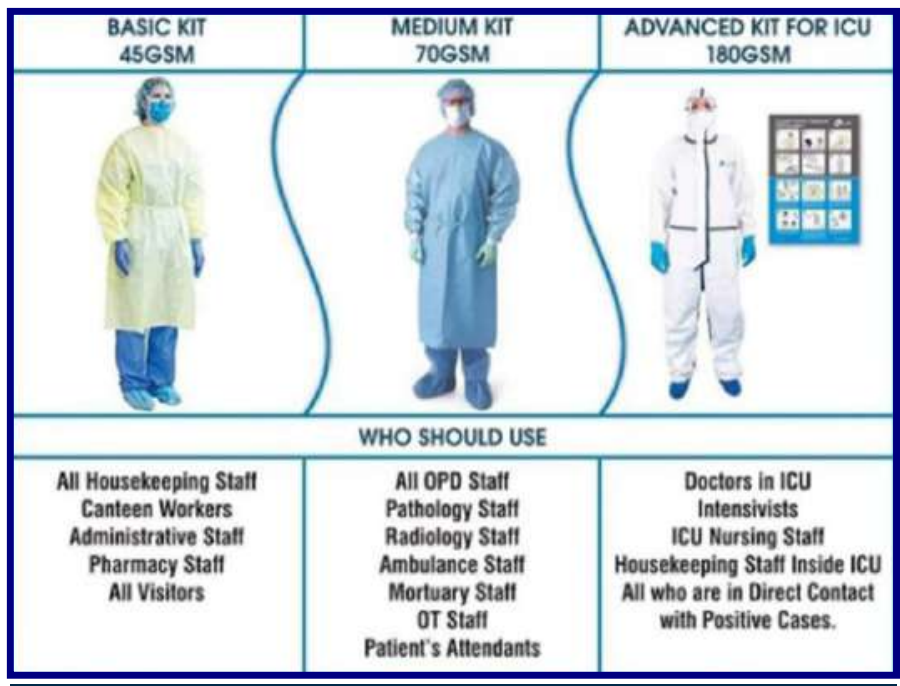

Figure 5. Personal protective equipment.

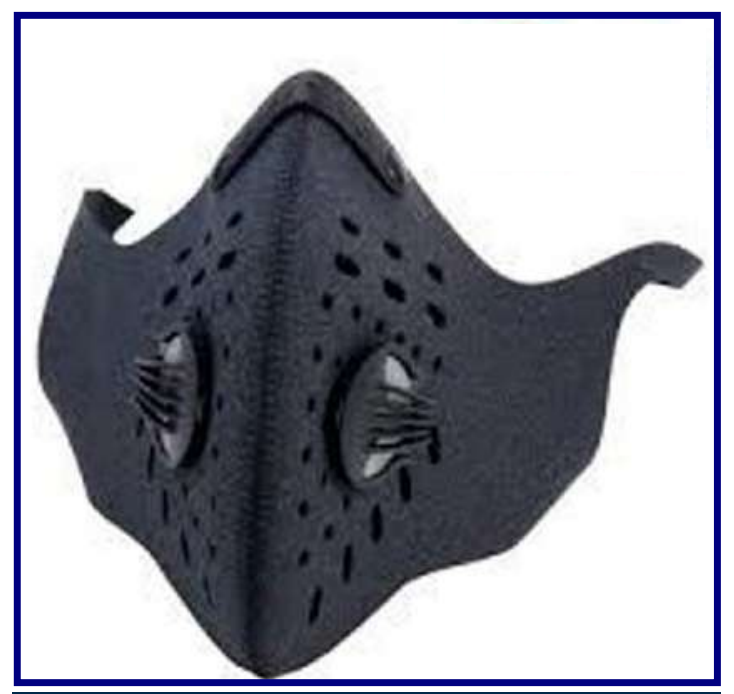

Figure 6. N-99 Face mask. 
Table 3. A guidance table showing the categories of dental treatments and the variety of treatments that can be provided for the patient during the COVID-19 pandemic (*Usually managed by oral and maxillofacial surgeons. **Pain assessment is carried out using the Universal Pain Assessment Tool (UPA)] [18].

A

Emergency.

\section{B}

C

Urgent conditions that can be managed with minimally invasive procedures and without aerosol generation.
Urgent conditions that Non urgent

D

E

\begin{tabular}{|c|c|c|c|c|}
\hline $\begin{array}{l}\text { Unstable maxillofa- } \\
\text { cial fractures that can } \\
\text { compromise patients } \\
\text { airway. }\end{array}$ & $\begin{array}{l}\text { Severe dental pain } \\
\text { from pulpal inflam- } \\
\text { mation that requires } \\
\text { tooth extraction. }\end{array}$ & $\begin{array}{l}\text { Severe dental pain } \\
\text { from pulpal inflamma- } \\
\text { tion that need to be } \\
\text { managed with aerosol } \\
\text { generating procedures }\end{array}$ & $\begin{array}{l}\text { Removable } \\
\text { denture } \\
\text { adjustments and } \\
\text { repair. }\end{array}$ & $\begin{array}{l}\text { Initial or period- } \\
\text { ic oral examina- } \\
\text { tions and recall } \\
\text { visits. }\end{array}$ \\
\hline $\begin{array}{l}\text { Diffuse bacterial soft } \\
\text { tissue infection with } \\
\text { intraoral/extraoral } \\
\text { swelling that can } \\
\text { compromise patients } \\
\text { airway. }\end{array}$ & $\begin{array}{l}\text { Severe dental pain } \\
(7 \leq) \text { from fractured } \\
\text { vital tooth that can be } \\
\text { managed without } \\
\text { aerosol generation** }\end{array}$ & $\begin{array}{l}\text { Severe dental pain } \\
(7 \leq) \text { from fractured } \\
\text { vital tooth that need to } \\
\text { be managed with } \\
\text { aerosol generating } \\
\text { procedures** }\end{array}$ & $\begin{array}{l}\text { Asymptomatic } \\
\text { fractured or } \\
\text { defective } \\
\text { restoration. }\end{array}$ & $\begin{array}{l}\text { Aesthetic dental } \\
\text { procedures. }\end{array}$ \\
\hline \multirow[t]{6}{*}{$\begin{array}{l}\text { Uncontrolled postop- } \\
\text { erative bleeding. }\end{array}$} & $\begin{array}{l}\text { Dental trauma with } \\
\text { avulsion/luxation } \\
\text { that can be minimally } \\
\text { managed without } \\
\text { aerosol generation. }\end{array}$ & $\begin{array}{l}\text { Dental trauma with } \\
\text { avulsion/luxation that } \\
\text { need invasive/Aerosol } \\
\text { Generating Proce- } \\
\text { dures. }\end{array}$ & $\begin{array}{l}\text { Asymptomatic } \\
\text { fractured or de- } \\
\text { fective fixed pros- } \\
\text { thesis. }\end{array}$ & $\begin{array}{l}\text { Restorative } \\
\text { treatment of } \\
\text { asymptomatic } \\
\text { teeth. }\end{array}$ \\
\hline & $\begin{array}{l}\text { Surgical postopera- } \\
\text { tive osteitis or dry } \\
\text { socket that can be } \\
\text { managed without } \\
\text { aerosol generation.* }\end{array}$ & $\begin{array}{l}\text { Deboned fixed pros- } \\
\text { thesis cleaning and } \\
\text { temporary cementa- } \\
\text { tion. }\end{array}$ & $\begin{array}{l}\text { Asymptomatic } \\
\text { fractured or de- } \\
\text { fective orthodon- } \\
\text { tic appliance. }\end{array}$ & $\begin{array}{l}\text { Extraction of } \\
\text { asymptomatic } \\
\text { teeth. }\end{array}$ \\
\hline & $\begin{array}{l}\text { Pericoronitis or third } \\
\text { molar pain that can } \\
\text { be managed without } \\
\text { aerosol generation. }\end{array}$ & $\begin{array}{l}\text { Removable dentures } \\
\text { adjustments for radia- } \\
\text { tion/oncology } \\
\text { patients. }\end{array}$ & $\begin{array}{l}\text { Chronic perio- } \\
\text { dontal disease. }\end{array}$ & $\begin{array}{l}\text { Orthodontic pro- } \\
\text { cedures other } \\
\text { than those in } \\
\text { category } B / C \text {. }\end{array}$ \\
\hline & $\begin{array}{l}\text { Stable maxillofacial } \\
\text { fractures that re- } \\
\text { quires no interven- } \\
\text { tion.* }\end{array}$ & $\begin{array}{l}\text { Fractured or defective } \\
\text { fixed prosthesis caus- } \\
\text { ing soft tissue injury. }\end{array}$ & & $\begin{array}{l}\text { Routine dental } \\
\text { cleaning and } \\
\text { preventive } \\
\text { therapies. }\end{array}$ \\
\hline & $\begin{array}{l}\text { Localised dental/ } \\
\text { periodontal abscess } \\
\text { that can be managed } \\
\text { without aerosol } \\
\text { generation. }\end{array}$ & $\begin{array}{l}\text { Acute periodontal dis- } \\
\text { ease. }\end{array}$ & & $\begin{array}{l}\text { Replacement of } \\
\text { missing tooth/ } \\
\text { teeth with fixed } \\
\text { or removable } \\
\text { prosthesis. }\end{array}$ \\
\hline & $\begin{array}{l}\text { Fractured or defec- } \\
\text { tive fixed orthodontic } \\
\text { appliance causing soft } \\
\text { tissue laceration. }\end{array}$ & & & $\begin{array}{l}\text { Dental implant } \\
\text { surgery. }\end{array}$ \\
\hline
\end{tabular}

cautiously assess suitable PPE's availability to minimise virus transmission risk (Figure 5).

\subsection{Dental Health Care Personnel Considerations}

- Dentists will consult with all workers to present the protocols and guidance for COVID-19.

- Strict adherence to hand hygiene, including: prior to and during patient contact; after contact with contaminated surfaces or equipment; and after
PPE has been removed.

- Ensure that the dental health care staff has received their seasonal flu vaccine.

- Regular Staff Health Screening: Take the temperature of the staff before starting the workday. When over 100.4 degrees, workers are sent home or referred to a testing facility. Staff respond to regular questionnaire answers. Refer to a testing centre if you answer "yes" to any questions [19]. 


\subsection{COVID-19 questionnaire}

a. Do you have any of the following signs of respiratory problems? Fever, Sore Throat, Cough, Breathing Shortage?

b. Have you lost your sense of smell or taste recently?

c. Do you have any gastro-intestinal symptoms? Diarrhoea? Nausea?

d. 4. Also if you do not have any of the above symptoms at the moment, have you felt any of those symptoms in the last 14 days?

e. Have you been in touch with anyone over the last 14 days who have tested positive for COVID-19?

f. Have you travelled outside the country by air or cruise ship in the past 14 days?

g. Have you travelled within the country by air, bus or train within the past 14 days?

If DHCP is sick, tests positive for COVID-19, or is caring for an individual that tested positive for COVID-19, the DHCP should not report to work [20].

\subsection{Patient pre-appointment screenings}

- Screen all patients before scheduling. Advise patients to monitor their home temperature. If it's below 100.4 degrees, then it's fine.

- Absolute registration of patients via telephone or secure email before arriving at the office.

- Administer COVID-19 questionnaire:

- Positive responses to COVID-19 questionnaire. Refer the patient to the primary health care provider. Do not schedule the patient for dental treatment [21].

- If the patient reports no symptoms, no possible contact with COVID-19 infected person, no suspicious travel, and no fever, schedule the patient for a dental appointment.

- To minimize potential contact with other patients in the waiting room, schedule separate appointments where possible [19].

\subsection{Reminders to patients}

- Recall patients to restrict the number of companions.

- Depending on office size, companions may need to remain in their vehicles or outside the dental office [22].

- Patient face masks-encourage patients to wear a face mask/covering as they enter and leave the exercise.

- $\quad$ Provide patients with guidelines by (i) keeping six feet as far as possible from all other individuals, (ii) hand hygiene, and (iii) respiratory and cough etiquette [23].

\subsection{Clinical setting}

6.6.1 In-Office Patient Registration Procedures

- Have hand sanitizer available for use (ideally $60 \%$ or better).

- Consider using automatic opening trash cans.

- Check patient's temperature (with a thermometer (where possible a touchless forehead scan) [21].

- Reappoint and refer if the patient's temperature rises above the threshold of $100.4 \mathrm{~F}$ to their primary care physician.

- Complete Patient's Screening Form. Positive answers to all of these questions, consider referring to their primary care doctor or emergency care at this time or request further information on their primary care doctor or emergency care.

- Consider pre-treatment registration remotely, to minimize in-office contact with staff.

- Do not carry the paper records of the patient into the operative [24].

\subsubsection{Reception Area Preparation Strategies}

Get your dental office ready for COVID-19. Via this checklist, secure the patients and employees. Emphasize hand hygiene and cough etiquette for everyone.

- Prepare the building or office entrance: provide hand sanitation before entering the facility with a warning to individuals to use it before entering into office.

- Consider providing the patient with a mask to be worn in the office, exceptfor the dental treatment [24].

- Providing waiting areas, toilets and tissue treatment rooms for patients, alcohol-based hand cleanser, sink cleaner, garbage cans.

- $\quad$ Place chairs 6 feet apart, when possible.

- Delete toys, materials for reading, remote controls, or other general items.

- Wipe away all touchable surfaces with an authorised surface cleaner on a daily schedule.

- For example, tables, chair arms, doorknobs, light switches, hangers, and any other objects with which individuals may have direct contact. Using products which meet the EPA requirements for use against SARS-CoV to disinfect.

- Recall that patients limit their number of companions.

- Companions may need to remain in their cars or outside the dental office, depending on the office size [24]. 


\subsubsection{Chairside Checklist}

Dentists and staff may use this checklist to prepare the procedures during and after the patient's visit to the operating rooms for work.

Use the highest level of PPE available: PSA available: Physical strategies to interrupt or suppress the spread of respiratory viruses are: periodic hand washing (55\%), mask-wearing (68\%), gloves wearing (57\%), gown wearing (77\%); when taken together if the clinician uses full "reasonably readily available universal precautions including mask, gloves, gown and washes their hands before and after patient contact, they have a 0.09 odds ratio of contracting the disease $(91 \%$ reduced chance) [25].

- If available, wear a mask, gloves, a gown, eye protection (i.e., goggles or disposable/reusable face shield covering the face's front and sides).

- If aerosols are predicted, use the highest available PPE level and recommend a respirator mask equal to N95 or N95.

- If there is no respirator (N95 or equivalent) available, use a surgical mask and face shield combination (Figure 6).

- After leaving the patient's room, respirators should be removed (and, if disposable, discarded).

- Reusable eye protection prior to reuse should be swept and disinfected.

- Clothing - Gowns: Suggest gowns for solitude. After utilisation, disposable gowns should be discarded in a dedicated waste container. After each use cloth isolation gowns should be laundered. Recommend changing gowns during aerosol processing procedures Scrubs: When scrubs are worn, change from regular clothes to intro scrubs at the dental office. Before you leave the dental office, change out of scrubs and back into normal clothes. Scrubs should be washed after or at the end of the day after soiling.

- $\quad$ Ensure strict adherence to hand hygiene by DHCP procedure, including prior to and after patient touch, after contact with polluted surfaces or equipment, after removal of PPE.

- Limit organisational paperwork to the greatest extent possible.

- Cover a keyboard machine with a transparent versatile, disposable barrier and patient shift.

- Limit patient access to the operator only, if necessary. Offer someone who accompanies the patient a mask.

- Hold operational staff levels to the minimum required.
- Mask pre-entry (including chairside staff), as virus -containing aerosol particles may exist.

- No physical contact or handshaking.

- Wash hands and glove in the operatory

- Review overall health background, confirm that the screening questions were asked during checkin and, if possible, review.

- $\quad$ Consider pre-treatment rinses to decrease bacterial and viral loads in aerosols.

- Usage of clinical judgment when offering some restoration or hygiene treatment to use the lowest aerosol-generating armamentarium. Using hand scaling instead of sonic/ultrasonic scaling where required. When possible, high-speed evacuations should be used.

- Consider restorative processes conducted under a rubber dam or similar (such as Isolite or Dry Shield).

- Usage of nitrous oxide: use of disposable nasal hood; either disposable or sterilized tubing should be used.

- Shock the waterlines of your dental unit if you return from an extended break in practice.

- Use professional judgement on mask/gown removal and replacement between patients if aerosols are not produced.

- Clean the operator with gloves, mask, face shield or goggles when wearing.

- Dispose and repair surface barriers after each patient's use.

- Clean detergent soap surfaces, accompanied by cleanser disinfection, use products that meet SARS -CoV-22 EPA requirements.

- Provide a mask for the patient and escort the patient from the office [17].

\subsubsection{Post-procedure protocol:}

- Consider delaying entry into a room where aerosols have been produced for as long as possible, up to three hours if possible.

- Guide patients as they exit the office to use their face coverings. Aim to prevent patients from moving close to each other and clean all surfaces that touch the patient.

- Wherever practicable, restrict the transfer of paperwork. Consider submitting credit card receipts and invoices via email or mail. Use payment card passing gloves and facilitate contactless methods of payment.

- Disinfect the areas entered by a patient or visitor, including door handles, chairs, and bathrooms. 
- Limit follow up appointments. Consider resorbable sutures and tele-dentistry.

- Call patients 4-7 days after appointment to confirm that they do not have any COVID-19 symptoms with the same pre-appointment interview questionnaire.

- If you need to remind patients of potential exposure, keep a record of the patient schedule.

- Instruct the patient to contact the office within 14 days after the dental consultation if they develop COVID-19 symptoms.

- Consider protocol changes before successful and accurate mass immunity testing and vaccination with COVID-19 is accessible [21].

\subsubsection{Office Considerations}

- Have a transparent barrier separating front desk employees from patients, if necessary. Otherwise, when performing office duties such as accepting payments, arranging future meetings, etc., aim to maintain distance between the front desk and patients.

- Place barriers where possible to protect hightouch objects [19].

- Have hand sanitizer available for use in an automatic dispenser (ideally $60 \%$ alcohol or better).

- Disinfect the waiting area between patients, in addition to the periodic disinfection procedure.

- In addition to the standard disinfection protocol, disinfect operatory between patients [25].

- Disinfect high touch surfaces often.

- Limit the number of patient-surgical staff.

- In the light of patient needs and risk, dentists should decide on patient care using independent clinical judgement. In all care situations, some risk to DHCP and patient is inherent and differs from the PPE level used when treating patients.

- Use professional judgement to limit aerosolgenerating procedures and employ the lowest aerosol-generating procedures whenever possible. Hand-scale rather than ultrasonic scale, if possible.

- Treating higher-risk patients: COVID-19 is a new disease, and little information is available on risk factors of severe illnesses. Consider separate office hours for patients at higher risk due to comorbidities or age [23].

\section{Conclusion}

Management of COVID-19 is an essential part of clinical practice. Most dental operatories are closed today to prevent the spread of the covid virus, causing undue apprehension among dental professionals. Dentists should have adequate knowledge in managing emergencies during this pandemic by adhering to strict protocols and reducing infection transmission to others and beyond.

Conflicts of interest: Authors declared no conflicts of interest.

Financial support: None

\section{References}

1. Mahdi SS, Ahmed Z, Allana R, Peretti A, Amenta F, Nadeem Bijle M, Seow LL, Daood U. Pivoting Dental Practice Management during the COVID-19 Pandemic-A Systematic Review. Medicina. 2020;56 (12):644. https://doi.org/10.3390/medicina56120644

2. Wang C, Horby PW, Hayden FG, Gao GF. A novel coronavirus outbreak of global health concern. The Lancet. 2020;395(10223):470-3. https://doi.org/10.1016/S0140-6736(20)30185-9

3. Coronavirus SARS-CoV-2 I COVID-19 pandemic: Information and Guidelines for Pharmacists and the Pharmacy Workforce (Internet).

4. Brahmanandam PS, Chakravarthy KK, Raju GR, Rao NS, Satyavani M, Kumar VN, Alla RK, Kadiyala KG, Vinay P, Rao C, Narsaiah EL. Feasible Solutions and Role of Nanomaterials in Combating the COVID19 Pandemic: A Preliminary Study. Trends in Biomaterials \& Artificial Organs. 2020 Jul 3;34.

5. Richman DD, Whitley RJ, Hayden FG, editors. Clinical virology. John Wiley \& Sons; 2016 Dec 1. https://doi.org/10.1128/9781555819439.ch1

6. Gralinski LE, Menachery VD. Return of the coronavirus: 2019-nCoV. Viruses 12: 135. https://doi.org/10.3390/v12020135

7. Zhou P, Yang XL, Wang XG, Hu B, Zhang L, Zhang W, Si HR, Zhu Y, Li B, Huang CL, Chen HD. A pneumonia outbreak associated with a new coronavirus of probable bat origin. nature. 2020;579 (7798):270-3. https://doi.org/10.1038/s41586-020-2012-7

8. Lu CW, Liu XF, Jia ZF. 2019-nCoV transmission through the ocular surface must not be ignored. Lancet (London, England). 2020;395(10224):e39. https://doi.org/10.1016/S0140-6736(20)30313-5

9. Zhang H, Kang Z, Gong H, Xu D, Wang J, Li Z, Cui X, Xiao J, Meng T, Zhou W, Liu J. The digestive system is a potential route of $2019-n C o v$ infection: a bioinformatics analysis based on single-cell transcriptomes. BioRxiv. 2020 Jan 1. https://doi.org/10.1101/2020.01.30.927806

10. Peng X, XuX, Li Y, Cheng L, Zhou X, Ren B. 


\section{Transmission routes of $2019-\mathrm{nCoV}$ and controls in dental practice. Int J Oral Sci. 2020;12(1):1-6. https://doi.org/10.1038/s41368-020-0075-9}

11. World Health Organization. Global surveillance for COVID-19 caused by human infection with COVID19 virus: interim guidance, 20 March 2020. World Health Organization; 2020.

12. He X, Lau EH, Wu P, Deng X, Wang J, Hao X, Lau YC, Wong JY, Guan Y, Tan X, Mo X. Temporal dynamics in viral shedding and transmissibility of COVID-19. Nature medicine. 2020;26(5):672-5. https://doi.org/10.1038/s41591-020-0869-5

13. Wei WE, Li Z, Chiew CJ, Yong SE, Toh MP, Lee VJ. Presymptomatic Transmission of SARS-CoV2-Singapore, January 23-March 16, 2020. Morbidity and Mortality Weekly Report. 2020 Apr 10;69 (14):411. https://doi.org/10.15585/mmwr.mm6914e1

14. Cascella M, Rajnik M, Cuomo A, Dulebohn SC, Di Napoli R. Features, evaluation and treatment coronavirus (COVID-19). InStatpearls [internet] $2020 \mathrm{Mar}$ 8. StatPearls Publishing.

15. Coulthard P. Dentistry and coronavirus (COVID-19)moral decision-making. Brit Dent J. 2020;228(7):503 -5. https://doi.org/10.1038/s41415-020-1482-1

16. Meng L, Hua F, Bian Z. Coronavirus disease 2019 (COVID-19): emerging and future challenges for dental and oral medicine. J Dent Res. 2020;99(5):481 -7. https://doi.org/10.1177/0022034520914246

17. Alharbi A, Alharbi S, Alqaidi S. Guidelines for dental care provision during the COVID-19 pandemic. Saud Dent J. 2020;32(4):181-6. https://doi.org/10.1016/j.sdenti.2020.04.001

18. Kohn WG, Collins AS, Cleveland JL, Harte JA, Eklund KJ, Malvitz DM. Guidelines for infection control in dental health-care settings-2003.

19. American dental association: interim mask and face shield guidelines

20. American Dental Association. ADA interim guidance for minimizing risk of COVID-19 transmission.

21. CDC: steps healthcare facilities can take now to prepare for COVID - 19.

22. CDC: interim clinical guidance for management of patients with confirmed coronavirus disease (COVID -19).

23. CDC: interim infection prevention control guidance for dental settings during COVID-19 response.

24. Jefferson T, et al: Physical interventions to interrupt or reduce the spread of respiratory viruses: systematic review. BMJ 2008;336(7635): 77-80. https:// doi.org/10.1136/bmj.39393.510347.BE

25. CDC: Interim Infection Prevention and Control Guidance for Dental Settings During the COVID-19 Response EPA Disinfectants List N: Disinfectants for Use Against SARS-CoV-2. 